\title{
Primary Health Care
}

\section{Research \& Development}

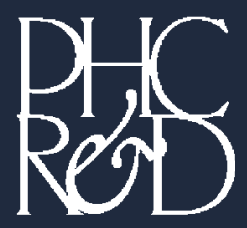




\section{PRIMARY HEALTH CARE \\ RESEARCH \& DEVELOPMENT}

\section{EDITORS}

Professor Sally Kendall Professor of Nursing, CRIPACC, University of Hertfordshire, Hatfield, UK

Professor Ros Bryar Professor of Community and Primary Care Nursing, City University, London, UK

\section{NETWORKING EDITOR \\ Dr Jonathan Graffy \\ Senior Clinical \\ Research Fellow, University of Cambridge, Cambridge, UK}

\section{PUBLICATIONS REVIEW EDITOR}

Dr Maxine Offredy Publications Review Editor, Reader in Primary Health Care, CRIPACC, University of Hertfordshire, Hatfield, UK

\section{SOCIETY FOR ACADEMIC PRIMARY CARE REPRESENTATIVE*}

Dr Peter Murchie

Senior Clinical Lecturer in Primary Care, Department of General Practice \& Primary Care, University of Aberdeen, Aberdeen, UK

\section{EDITORIAL} ASSISTANT

Michelle Varian CRIPACC, University of Hertfordshire, Hatfield, UK
EDITORIAL BOARD

Dr Ann Adams

Principal Research Fellow, Health Sciences Research Institute, University of Warwick, Coventry, UK

Professor John Beasley

Emeritus Professor, Department of Family Medicine, University of Wisconsin,

Wisconsin, USA

Dr Jeanne Besner

Adjunct Assistant

Professor, Director, Initiatives in Nursing Research, University of Alberta, Calgary,

Alberta, Canada

Professor Ruth Bindler

Director of PhD

Programs, College of

Nursing, Washington

State University, Spokane, USA

Dr Fiona Brooks

Reader in Primary Health

Care, CRIPACC, University of Herts,

Hatfield, UK

Professor Sarah Cowley

Professor of Community

Practice Development,

Kings College,

London, UK

Ms Sirkka Eramaa

Mikkeli Polytechnic,

Savonlinna School of

Health Care, Savonlinna,

Finland
Dr Heather Gage

Senior Lecturer in

Economics, Department

of Economics,

University of Surrey,

Guildford, UK

Professor Katarina Hjelm

School of Health Sciences

\& Social Work,

Linnaeus University,

Sweden

Professor Pali Hungin

Director, Centre for

Integrated Health Care

Research, Head of

School for Health,

Dean of Medicine,

University of Durham,

Durham, UK

Dr Steve Iliffe

Reader in General

Practice, Primary Care

and Population Sciences,

University College,

London, UK

Professor Chungnam Kim

President,

Korean Academy of

Community Nursing,

Keimyung University,

Korea

Professor Susan Latter

Professor of Primary

and Community Care,

University of Southampton,

Southampton, UK

Professor John Macdonald

Foundation Chair in

Primary Health Care,

University of Western

Sydney, Sydney,

Australia
Professor Jill Manthorpe

Professor of Social Work,

Social Care Workforce

Research Unit,

Kings College London,

London UK

Professor Geoff Meads

Visiting Professor of

Organisational Research,

Centre for Primary

Health Care Studies,

Warwick Medical School,

Coventry, UK

Dr Pauline Pearson

Senior Lecturer

in Primary Care

Nursing, School of

Medical Educational

Development,

University of Newcastle,

Newcastle, UK

Professor Anne Rogers

Professor of the Sociology

of Health Care,

School of Medicine,

University of Manchester,

Manchester, UK

Professor Helen Smith

Chair of Primary Care,

Brighton \& Sussex

Medical School,

University of Brighton,

Brighton, UK

Professor Chris Van Weel

Professor of General

Practice, Department of

General Practice,

University Medical

Centre, Nijmegen, The

Netherlands and

President of the World

Organisation of Family

Doctors

*All members of The Society for Academic Primary Care (www.sapc.ac.uk) automatically receive a print and online subscription to Primary Health Care Research \& Development. 


\section{Volume 12, Number 2, April 2011 \\ PRIMARY HEALTH CARE \\ RESEARCH \& DEVELOPMENT}

\section{CONTENTS}

\section{Editorial}

Academic Primary Care: time to review and integrate

Ann Adams, Helen Lester, Sally Kendall and Ros Bryar

\section{Development}

Development and application of the Imperial College Obesity Strategy Assessment Framework for analysing local obesity strategies

Nik A.A. Tuah, Samrina Qureshi, Waljit S. Dhillo and Azeem Majeed

A service model for delivering care closer to home

Joanna Dodd, Charlotte Elizabeth Taylor, Paul Bunyan, Philippa Mary White, Siân Myra Thomas and

Dominic Upton

\section{Research}

Factors influencing engagement of patients in a novel intervention for CFS/ME: a qualitative study

Carolyn Chew-Graham, Joanna Brooks, Alison Wearden, Christopher Dowrick and Sarah Peters

The frequency distribution of presenting symptoms in children aged six months to six years to primary care

Sara Whitburn, Céire Costelloe, Alan A. Montgomery, Niamh M. Redmond, Margaret Fletcher, Tim J. Peters and Alastair D. Hay

Investigation of the oral health needs for homeless people in specialist units in London, Cardiff, Glasgow and Birmingham

Kirsty B. Hill and Debbie Rimington

Improving the utilization of health and nutrition services: experience from the Catholic Relief Services supported the Development Assistance Programme in Ghana

Mahama Saaka and Sylevester Galaa

The epidemiology of patellofemoral disorders in adulthood: a review of routine general practice morbidity recording

Laurence Wood, Sara Muller and George Peat

The experiences and needs of people seeking palliative health care out-of-hours: a qualitative study Suzanne H. Richards, Rachel Winder, Clare Seamark, David Seamark, Sarah Avery, James Gilbert, Angela Barwick and John L. Campbell

\section{Short Report}

Sickness certification for mental health problems: an analysis of a general practice consultation database Christian D. Mallen, Gwenllian Wynne-Jones and Kate M. Dunn

\section{Networking}

The Society for Academic Primary Care: Position Statement April 2011

\section{journals.cambridge.org/phc}


Primary Health Care Research \& Development (ISSN 1463-4236 print; ISSN 1477-1128 online) is published four times a year in January, April, July and October.

\section{1 annual subscription rates}

Volume 12 (4 issues) will appear in 2011. Organisational: $£ 281 / \$ 524$ (online \& print); $£ 185 / \$ 370$ (online only). Individual: $£ 90 / \$ 178$ (online \& print); $£ 68 / \$ 129$ (online only). All prices inclusive of postage.

Subscribers in Canada must add 7\% to the subscription price, to allow for GST. Subscribers in Europe must quote their VAT registration number or state that they are not registered. Subscribers in the following countries who are not VAT-registered must add VAT at the appropriate rate: Belgium (6\% TVA/BTW), France (2.1\% TVA), Germany (7\% MWST), Spain (4\% IVA), The Netherlands (6\% BTW).

\section{How to subscribe}

Post: Inquiries and orders for current subscriptions and back issues should be sent to: PHC Subscription Orders, Cambridge University Press Customer Services Department (Journals \& Online Publications), Edinburgh Building, Shaftesbury Road, Cambridge CB2 8RU, UK. Internet: journals.cambridge.org/phc Email: journals@ cambridge.org Tel: +44 (0)1223 326070. Fax: +44 (0)1223 325150.

\section{Change of address}

Please notify the subscriptions department. Send new address and postal code, and the address label from a current issue, to Journals Customer Services, Cambridge University Press, FREEPOST, The Edinburgh Building, Cambridge CB2 8RU, UK (no stamp necessary if posted within UK). Tel: +44 (0)1223 326070. Fax: +44 (0)1223 325150.

\section{Abstracting and indexing}

Primary Health Care Research \& Development is abstracted in: Academic Search Premier; British Nursing Index; PsycINFO; Cumulative Index to Nursing \& Allied Health Literature (CINAHL). From 2011 the Journal will be included in MEDLINE. Citations from the articles indexed, the indexing terms, and the English abstract printed in the journal will be included and searchable using PubMed.

\section{Advertisements}

For print and online advertisement rates, and information on advertisement copy, please contact PHC, Advertising Department, Cambridge University Press (Journals), University Printing House, Shaftesbury Road, Cambridge CB2 8BS, UK. Email: ad_sales@cambridge.org; Tel: +44 (0)1223 325083; Fax: +44 (0)1223 325801.

Cambridge University Press is a member of the HINARI programme (Health InterNetwork Access to Research Initiative; www.healthinternetwork.net). Organized by WHO, HINARI provides developing countries with access to one of the world's largest collections of biomedical and healthcare literature. By choosing to publish in Primary Health Care Research \& Development your paper will be available to developing countries who might otherwise not have had access.

All articles published in this journal are protected by copyright, which covers the exclusive rights to reproduce and distribute the article (e.g., as offprints), as well as all translation rights. No material published in this journal may be reproduced electronically, photographically, or stored on microfilm, in video disks, etc., without first obtaining written permission from the publishers. The use of general descriptive names, trade names, trademarks, etc., in this publication, even if not specifically identified, does not imply that these names are not protected by the relevant laws and regulations. While the advice and information in this journal are believed to be true and accurate at the date of its going to press, neither the authors, the editors, nor Cambridge University Press can accept any legal responsibility for any errors or omissions that may be made. The publisher makes no warranty, express or implied, with respect to the material contained herein. Cambridge University Press publishes advertisements in this journal while relying on the responsibility of the advertiser to comply with all legal requirements relating to the marketing and sale of products or services advertised. Cambridge University Press and the Editors are not responsible for claims made in the advertisements published in the journal. The appearance of advertisements in Cambridge University Press publications does not constitute endorsement, implied or intended, of the product advertised or the claims made for it by the advertiser.

This journal issue has been printed on FSC-certified paper and cover board. FSC is an independent, nongovernmental, not-for-profit organization established to promote the responsible management of the world's forests. Please see www.fsc.org for information.

(C) Cambridge University Press 2011

Printed by Latimer Trend, Plymouth, UK 